\title{
Coffee Farmers in Gayo Highlands: Comparison of Cultivation Practice between Farmers of Local Gayonese and Javanese Transmigrants
}

\author{
Muhammad Nazaruddin*, Abdullah Akhyar Nasution, Awaluddin and Ade Ikhsan Kamil
}

\author{
Social and Political Science Faculty, Malikussaleh University, Indonesia
}

\begin{abstract}
This study aims to describe the comparison of cultural values among coffee farmers with different ethnic backgrounds in Aceh Tengah and Bener Meriah District. The cultural values of coffee farmers who are transmigrants from Java showed different variations compared to those applied by the local Gayonese coffee farmers. Furhermore, this article explains the understanding and practice of cultural values and their implications in the system of coffee cultivation applied by transmigrant farmers from Java and those from local communities.

Data was collected by applying ethnographic method through Live In, participatory observation, and indepth interview. The results showed that there were different patterns of cultivation applied by farmers with gayo ethnic and Javanese migrants living in Gayo. The differences lie on the pattern of cultivation and planting, as well as on the symbolization of the coffee tree itself. The most outstanding difference is that local Gayonese coffee farmers apply local wisdom in the practice coffee cultivation and use the four elements of life symbols such as land, water, air and wind when seeing coffee as a source of livelihood in their lives.
\end{abstract}

Keywords: Coffee farmers, cultural values, Suistanability, environmental conservation.

\section{A. INTRODUCTION}

In general, the study on Value Orientation and Farmers Habitus (Study of Cultural Orientation and Behavior of Coffee Farmers in the Gayo Highlands) is one of the introductory studies on coffee farmers which may be part of the basic reason why the following study was conducted (Nazaruddin et.al. 2019). Firstly, knowledge about coffee that has grown and is rooted in the life of the Gayo community is generically constructed with inheritance patterns that apply from previous generations; Secondly, life experiences, social practices, systems, rules and organized habits among Gayo coffee farmers are important factors in shaping the farming habitus of the Gayo community, and; Thirdly, there has been a change in the orientation of the value of life in Gayo society. In this case, the orientation is cumulative. Initially, the orientation of coffee cultivation was only as a fulfillment of primary living needs, but now it has developed into a tertiary life fulfillment due to the commodification of materiality (Kamil, 2019). This condition has a correlation with the goal of working to get social recognition; and fourth, coffee is not only a commodity with economic value, but it is also present as a medium for cultural diplomacy that grows and develops in Acehnese society in particular and Indonesia in general.

*Address correspondence to this author at the Social and Political Science Faculty, Universitas Malikussaleh, Lhokseumawe, Aceh, Indonesia; Tel: +62645-41373; Fax: +62-645-59089; E-mail: muh.nazaruddin@unimal.ac.id
When we see at local context that Aceh Province is the largest producer of arabica coffee in Indonesia with its production centers in Gayo highlands, namely, districts of Central Aceh, Bener Meriah, and Gayo Lues. The Central Statistics Agency (BPS, 2018) released that, in 2018, Aceh Province became the fourth largest coffee producer in Indonesia with a total production contribution of $9.08 \%$. Basically, the coffee farming community in Gayo not only comes from the Gayo ethnic community, but instead most of them are Javanese transmigrant farmers. ${ }^{1}$ The difference between the two leads to differences in the cultural values of coffee and the way of cultivating coffee practiced by the two different groups of coffee farming ethnics.

This social discourse has helped shape the collective mind of the current coffee farming community, according to Bourdieu (Haryatmoko, 2016), tends to reduce the social to economic sphere which in turn leads to neglect of objective conditions in the process of planting objective social structures into the mental and subjective experience of the agent (Farmers from Javanese transmigrant). Among Javanese peasants, the habitus system is timeresistant and can be inherited, the structures are intended to function as an alternative to the solutions offered to become capabilities that seem natural and develop in the social environment.

${ }^{1}$ We use the term of Coffee Farmers who come from local communities with an ethnic Gayo background and Coffee Farmers from Transmigrant Java is based on the differentiation of their farming practices. 
The cultural values of transmigrant farmers from Java in the Gayo highlands are indirectly different from those of the Gayo peasants. The cultural value of farming transmigrant farmers from Java prioritizes coffee production which can be economically profitable, so that in practice they are trapped in an effort to access the market without fully fulfilling the principles of sustainable agriculture, for example excessive use of pesticides which can interfere with the quality of coffee produced and part of it. don't make rorak. However, it is different from the cultural value of coffee and Gayo farmers who depend on coffee and from the coffee trade, whose farming methods promote cultural values that have been applied by local wisdom from generation to generation only by caring for coffee organically without using too much treatment. unorganic, although productivity is not stable in each harvest season (Puspitawati et al. 2020). In addition, in the fertilization process, the local wisdom of coffee farmers from Gayo is also directly proportional to adaptation to climate change and the fulfillment of sustainable agricultural practices with the application of variations in protective crops for making rorak and making efforts to conserve water resources (Achwan et al., 2019)

However, the production of Javanese farmers is more economically abundant than Gayo farmers production, by only relying on 'what they consider natural' methods. This is reflected in the increasing number of transmigrant farmers from Java who have increased their economic income. In contrast to Gayo farmers who still maintain the cultural value of traditional coffee care. Many factors influence and maintain the cultural values of Gayo farmers traditionally. The factor of wanting to maintain the quality and purity of the original Gayo coffee identity so as not to damage its image and image is one of the most decisive reasons. Even though the margins are quite far between Javanese farmers and Gayo farmers in getting profits, the margins of Javanese farmers are getting higher, in other words when the coffee production of Javanese farmers increases, the economy of Javanese coffee farmer families and the welfare of Javanese farmers is much more improved compared to Gayo farmers.

Currently, the dynamics related to the standard of sustainable farming practices continue to be echoed and even contested by various parties and actors with an interest in financing environmental protection through the Corporate Social Responsibility program (Levy et al. 2016). So that efforts to protect natural ecosystems through sustainable farming practices continue to urge farmers, even though farmers are willing to pay external costs in an effort to restore forest function on land planted with coffee (Prasmatiwi et al., 2011). Responding to the issues and phenomena that have developed where the Gayo coffee commodity which is "said" to be contaminated, clearly has a negative potential towards fulfilling the principles of Good Agricultural Practice which correlates with the improvement of the welfare of coffee farmers. However, the exploration of their cultural values helps explain their rationality in taking these actions.

Research related to coffee in this decade has focused more on efforts to fulfill the principles of sustainability and biodiversity Friendly (Gobbi, 2000) which is means such practices in agriculture to improve local food crop and directly proportional to the significance of the issue of free Trade Coffee. In their article about coffee protection plants in a non-biological aspect, they believe that the implementation of a sustainable project through shaded coffee is one of the most important elements to pay attention to (Toledo \& Moguel, 2012). They also identified and discussed four kinds of social and ecological values to coffee trees, which are important elements of the agroecosystem. First, ecological added value. Second, cultural diversity is related to agroforestry systems which include local knowledge of species diversity, ecological processes of managerial systems on coffee cultivation practices. The third is the diversity of livelihoods and their contribution to household welfare, and the last is the social and political implications, namely as a basis for forming the bargaining power of the farming community as an institution (Toledo \& Moguel, 2012).

Studies on the comparison of the cultural values of coffee in Indonesia, as on the researcher's opinion, have not been carried out yet. However, there are several previous studies on the study of coffee culture in Indonesia that can be used as references to show the state of the art of this study. Such as,(Nazaruddin, M., Nirzalin., Nasution Abdullah., Arifin, Awaludin., 2020) who examines the cultural dynamics of Coffee farmers, coffee-related research was also conducted by Devvany Gumulya and Ivana Stacia Helmi (2017) with the title "Study of the culture of drinking Indonesian coffee", as well as (Mahyuda; Amanah, Siti; Tjitropranoto, 2018) regarding the adoption rate of Good Agricultural Practices in Gayo Arabica Coffee Cultivation. by Farmers in Central Aceh District.

In the local context, the habit of coffee farmers is very important to be seen with regard to differences in 
treatment of coffee cultivation as the focus of research. In fact, studies related to socio-economic differences in the life of coffee farmers, such as comparisons of coffee farmers' habitus and cultural values, are actually a separate strength to strengthen solidarity related to the crisis experienced by coffee farmers, especially when dealing with low bargaining power on exportimport regulations. As said by Jaffee and Bacon (332) "we need to acknowledge the socio-economic and cultural differences and emphasizes ways to use these differences as a source of strength."

\section{B. METHODS}

This study was conducted in the Gayo highlands, precisely in Aceh Tengah, Bener Meriah districts. This location was chosen, apart from being the largest smallholder coffee producer in Aceh, but also related to the diversity of ethnic groups in Gayo. In addition, this location also attracts the attention of the author because the people are coffee farmers who have been cultivating coffee from generation to generation and have become the preference of current coffee developments in Aceh.

Data collection in this study was carried out through observations related to the lives of coffee farmers from the Javanese and Gayonese and events related to the world of coffee in the highlands of Tanah Gayo. In addition, survey methods and in-depth interviews were used with farmers who own coffee fields in the Gayo Highlands. There were 251 respondents who were sampled in this study. The goal is to find out how the knowledge and perceptions and patterns of coffee farmers in cultivating coffee throughout the season.

\section{RESULTS}

In general, the people of Gayo Highland have their main livelihood by farming and gardening coffee plants. Although at present changes to the economic system are unavoidable which results in the emergence of a number of new jobs and livelihoods which even become one of the main livelihoods apart from gardening and farming. From the observations that have been made, apart from farming, the general public also uses the land to raise livestock such as goats, chickens and cows, the Gayo community also cultivates intercropping plants such as potatoes and chilies. Therefore, the Gayo coffee farming system can also be categorized as a traditional polyculture system. As categorized by Moguel and Toledo (1999) (Toledo \& Moguel, 2012), this type shows that farmers convert native forests into gardens, which then with maintenance management including shade produce coffee production which is used for subsistence and for the purpose of accessing markets.

Some of the results of research that have been conducted, such as (Hidayat, 2017) explained that the characteristics of farmers are productive age that can cause farmers to have a better memory and have the courage to make decisions related to increasing production yields for a better life . In addition, with the existence of social media and the advancement of internet-based information, farmers of productive age have a better response to various changes and adaptations to technology.

Table 1: Distribution of Respondents Based on The Main Profession

\begin{tabular}{|c|c|c|c|}
\hline No & Main Profession & Numbers & $\begin{array}{c}\text { Percentage } \\
(\mathbf{\%})\end{array}$ \\
\hline \hline 1 & Local government staff & 1 & 0.4 \\
\hline 2 & Housewifes & 14 & 5.6 \\
\hline 3 & Fish Farmers & 3 & 1.2 \\
\hline 4 & Local Traders & 17 & 6.8 \\
\hline 5 & Farmers & 203 & 80.9 \\
\hline 6 & Civil Servants & 2 & 0.8 \\
\hline 7 & Forest Guards (POLHUT) & 1 & 0.4 \\
\hline 8 & Businessmen & 10 & 4.0 \\
\hline & Total & 251 & 100 \\
\hline
\end{tabular}

Source: Research Data, 2020.

Table 1 shows the distribution of respondents based on their main occupation, the data shows that there are $20.1 \%$ or 48 coffee farmers who own land who also have other jobs which are their main occupations. The remaining $80.9 \%$ of respondents or 203 respondents made coffee their main livelihood commodity for their family households. Some of the main occupations of respondents other than coffee farmers also have very diverse main jobs, namely as fishermen, traders, civil servants, forest policemen, entrepreneurs, housewives, and local village officials.

In addition, if it is seen from the diversity of the main occupations of coffee farmers today, it shows that there are significant developments related to coffee farming as a job in the knowledge of the community in the Gayo Highlands. Because when viewed from the developments in the last few decades, coffee farmers in Gayo are farmers with different characteristics and 
land area from large farmers in large agricultural systems. With ownership of a land area that is not too large and a foundation to use production for family needs, the coffee farmers in Gayo tend to develop a survival strategy to face various risks they do not understand, one of which is the movement of world coffee prices.

Table 1 shows that one of the strategies developed by the farmers is to carry out several other jobs which are ultimately chosen to be the main job rather than being a coffee farmer, this is shown in Table 1. There are $20.1 \%$ of respondents who have main jobs other than being coffee farmer. In addition, coffee as a commodity has developed into a cash commodity.

With the development of people's livelihoods in the Gayo highlands, people has started to see that coffee is a source of cash that can also be an investment tool for additional income. At present, coffee farmers in Gayo highlands are no longer only from the local community, they have also begun to be adapted by various other communities who have migrated to Gayo highlands.

Table 2: Distribution of Respondents based on Ethnics

\begin{tabular}{|c|c|c|c|c|}
\hline \multirow[t]{2}{*}{ No } & \multirow{2}{*}{ Ethnics } & \multicolumn{2}{|c|}{ Sex } & \multirow{2}{*}{ Total } \\
\hline & & Male & Female & \\
\hline \multirow{2}{*}{1} & Gayonese & 92 & 27 & 119 \\
\hline & $\%$ & 36.7 & 10.8 & 47.4 \\
\hline \multirow{2}{*}{2} & Javanese & 106 & 23 & 129 \\
\hline & $\%$ & 42.2 & 9.2 & 51.4 \\
\hline \multirow{2}{*}{3} & Acehnese & 2 & 0 & 2 \\
\hline & $\%$ & 0.8 & 0.0 & 0.8 \\
\hline \multirow{2}{*}{4} & Bataknese (Toba) & 1 & 0 & 1 \\
\hline & $\%$ & 0.4 & 0.0 & 0.4 \\
\hline \multicolumn{2}{|r|}{ Total } & 201 & 50 & 251 \\
\hline \multicolumn{2}{|r|}{ Percentage (\%) } & 80.1 & 19.9 & 100 \\
\hline
\end{tabular}

Source: Research Data, 2020.

From the data collection, it was found that around $51.4 \%$ of farmers came from Javanese ethnic migrants, $47 \%$ of them came from Gayo and only $0.8 \%$ from Aceh and $0.4 \%$ from Toba (See Table 2). Judging from the table above, it can be seen that farmers outside of the local community have begun to make their livelihoods coffee. This shows that coffee has become a commodity that provides hope for an increase in social status among the Gayo community.

\section{DISCUSSION}

In general, there are two variants of coffee farming practices carried out by coffee farmers in the Gayo plains. These different cultivation practices show that there is different knowledge that underlies these coffee cultivation activities that come from practices, experiences, knowledge that are continuously carried out by two different groups of farmers. According to (Bourdieu, 2012), experience and knowledge are dispositions that can change according to certain arenas. Even the counciousness thaat has been formed is knowledge that has been internalized for a long time from the external including early Education from family and the other Environment which (Bourdieu, 1993) calls the process of incalculation. As explained (Nazaruddin et al. 2020) that:

"knowledge about coffee is largely a inheritance from previous generations. On average, today's farmers are the third generation. This behavior is formed as an awareness of the practice that remains in the lives of farmers because it has been present and internalized since they were young in their environment".

Knowledge about coffee is largely an inheritance from previous generations. On average, today's farmers are the third generation. This culture is formed as an awareness of the practice that remains in the farmers' life because it has been presented and internalized since they were young in their environment.

In addition, the Coffee farmers have a sense of pratique in Bourdieu' terms related to environmental, social, and cultural condition in the lives of both group farmers which then shaped their perceptions regarding the choices made in order to improve welfare and living standards through coffee farming. With different topographical conditions, elevations and land slopes, it provides a different experience to the knowledge of coffee farmers who are local communities in Gayo and coffee farmers who migrated to Gayo. This difference in knowledge and practice is one of the real conditions currently occurring in the lives of coffee farmers (Bourdieu, 1993).

In fact, the issue of different knowledge and practices related to coffee cultivation is not a big problem if the understanding of sustainable agriculture becomes the basis for regulation of world coffee trade. 
After coffee became one of the prima donna commodities that had high selling prices in the global market, various forms of market compulsion continued to be accepted by coffee producers who were farmers who owned small-scale plantations in the Gayo highlands. Various new concepts were introduced, such as environmentally friendly coffee cultivation, organic coffee cultivation, conservation coffee cultivation, and eco-labeling which means that coffee farming practices must be environmentally friendly, not destroy and open forest areas, and must pay attention to value added. economically related to shade trees planted between coffee trees. This means that the coffee farming pattern can simply be interpreted so that coffee farmers are in harmony with nature.

On this basis, currently various demands on global coffee farmers continue to arrive. Coffee farmers, both large and small, are continuously required to adapt the coffee cultivation pattern to the established environmentally friendly quality standards. Starting from planting, maintaining, selecting shade trees with the aim of maintaining sustainable production quality. This demand was of course greeted positively by coffee farmers in Central Aceh and Bener Meriah, because not only because these demands are mandatory, but also various global provisions are also ways and patterns of farming coffee farmers originating from Gayo in general. It has even become one of their strategies in overcoming climate change (Achwan et al., 2019)

However, recently Gayo coffee has begun to doubt the quality of its organic farming. Various issues that have developed which have become doubts among consumers have become a new problem for coffee farmers related to the excessive use of pesticides in the care and maintenance patterns of coffee trees. From the interviews conducted, several respondents confirmed that there was a different farming pattern than usual practiced by some farmers who wanted higher than usual production yields, he said that:
The news is splashy outside, but we're really okay here. That's why we thought someone was playing here. If you say organic, it is not completely organic. Because they still use fertilizer. However, unlike others in terms of use both in type and quantity. So excited outside of us, so keep going. But these are not direct farmers, sir ... because even if we bring them, we don't necessarily really understand this issue. If this includes Pak Hamdani, the farmer is also a coffee trader. And this is also a village assistant too. Which is also a motivator in society.

The problem of treatment using pesticide fertilizers is one of the treatment patterns that have begun to be used by several groups of farmers who come from immigrant communities who have started to arrive and have gardens in the highlands of Gayo land. After coffee became a commodity with a fantastic selling price, outsiders began to arrive and introduce new agricultural patterns based on increasing productivity. As concluded by (Winarni, 2013) that:

"organic fertilizers are very effective
against the growth and development of
coffee plants, even the most effective is
goat manure which is added with the
bioactivator OrgaDec".

In the above diagram, it can be seen that the tendency of other communities started getting involved in the coffee. Therefore, the interest related to coffee plantation ownership has been increasing significantly in recent years. It was more than $50 \%$ of coffee plantation ownership is currently obtained from the buying and selling process, not from inheritance. It means that the ownership of coffee plantations has now begun shifting from the local community to the new comers. This means that coffee is a pure business by exploiting labors and capital to increase productivity for profits.

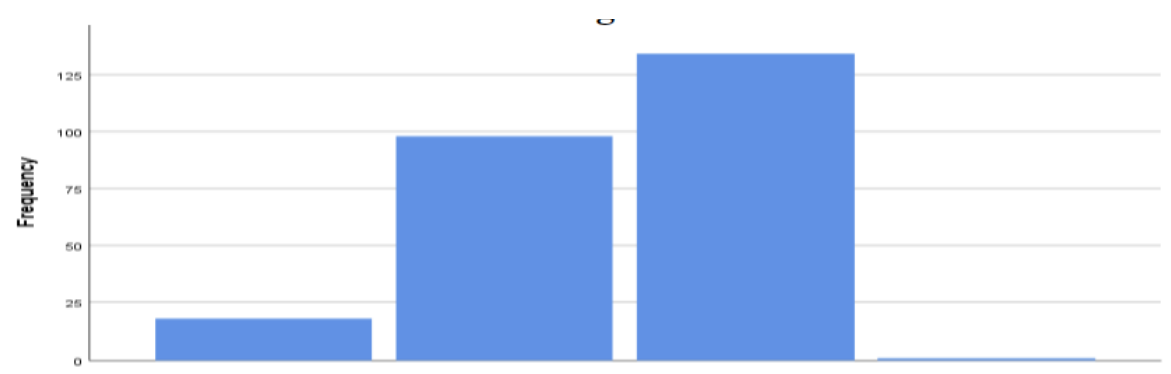

Figure 1: The production of Coffee Plantation. 
Some researchers do not deny that farmers in the Gayo highlands, apart from having a number of local knowledge and intelligence based on the environment in coffee cultivation (Mahyuda; Amanah, Siti; Tjitropranoto, 2018), they also have economic motive in coffee cultivation the plantation, as stated by (Nazaruddin et al., 2020)

Therefore, it is important for farmers to always increase their knowledge so that there is no mistreatment of farming. Approximately, a coffee tree needs 1 hour and 30 minute treatment a year. One coffee tree will produce $24 \mathrm{~kg}$ of cherries (red fruit) in one year. If it is processed for export quality, it will only get $3 \mathrm{~kg}$. One farming family can only work 1000 coffee sticks a year. If proper maintenance is carried out according to proper procedures, farmers can produce $3000 \mathrm{~kg}$ of coffee in a year. If the price per $\mathrm{kg}$ is $\$$ 4.5 , the farmer's annual income reaches approximately $\$ 14.482$.

The introduction of economic motives for increasing productivity among coffee farmers, both ethnic Gayo and Javanese, is common today. Especially after there was market pressure to harmonize a sustainable agricultural system. However, the difference between the two is obvious if you look at the cultural values in the coffee cultivation process. Although the selection of coffee types is currently almost uniform. As shown in Figure 2 below:

Different practices and knowledge will lead to different patterns of care, so that different variants of farming patterns emerge for farmers of both Gayo and Javanese. Coffee farmers with Gayo ethnic backgrounds apply 4 elements of life in the coffee cultivation process from each stage of farming practice. By prioritizing these elements of life, Gayo farmers harmonize the life elements of water, soil, air and wind during the coffee cultivation process. This can be revealed from the verse of 'siti kewe' which is read during the coffee seed planting process.

In addition, the effort to see coffee trees as analogous to humans in the sense of 'firstborn' has caused the treatment of farmers of Gayo ethnic background to be almost the same as the various demands categorized as sustainable agriculture. With a cropping pattern that has a shade tree and paying attention to the location when choosing land, it shows that the symbolization of analogue coffee with humans continues and this knowledge is continuously passed on to the next generation. As told by Pak Dian who is the second generation of coffee farmers in his extended family, he stated that:

"We communicate regularly with coffee, we talk to, so that it grows well and supports us with the amount of coffee produced every harvest season"

The most fundamental differences that we can see from the practice and knowledge between farmers of Gayo and Javanese communities in Central Aceh and Bener Meriah, are related to patterns of care and maintenance of the coffee plantation. Since the issue of pesticide use that disrupts the branding of Gayo coffee, which has been identical to organic, has emerged due to the use of pesticides to increase production. From

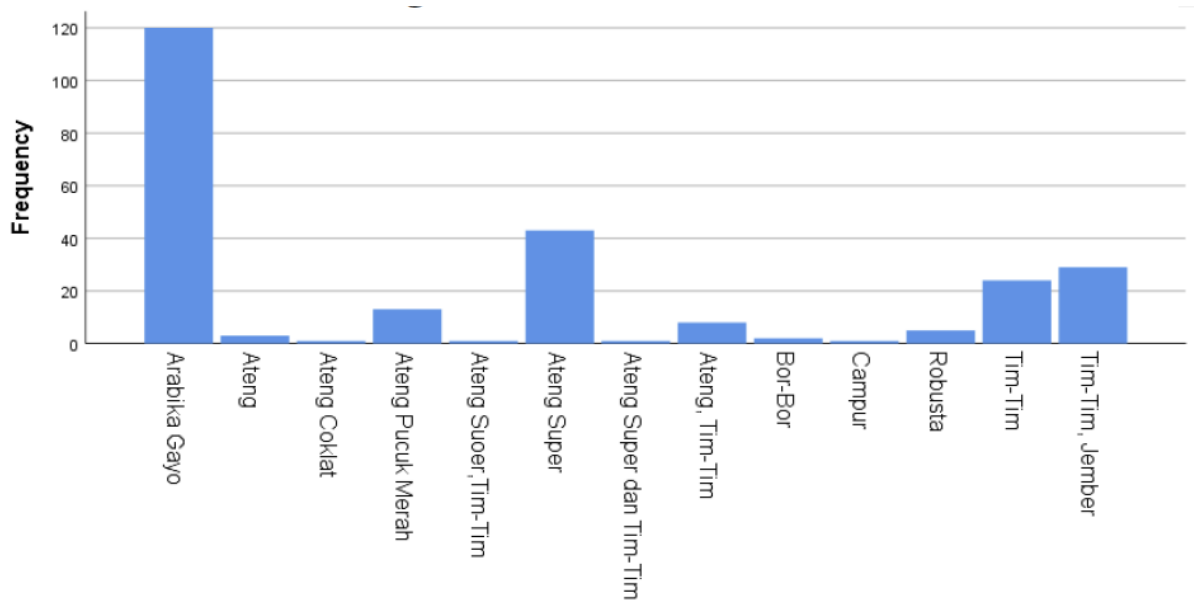

Figure 2: Coffee Varieties.

Source: Research Data, 2020. 
Table 3: Types of Coffee Plant Care Based on Ethnics Affliation

\begin{tabular}{|c|c|c|c|c|c|}
\hline \multirow{2}{*}{ Type of Coffee Plant Care } & \multicolumn{5}{|c|}{ Ethnics } \\
\hline & Gayonese & Javanese & Acehnese & Bataknese (Toba) & Total \\
\hline Organics & $\begin{array}{c}54 \\
21,5 \%\end{array}$ & $\begin{array}{c}13 \\
5,2 \%\end{array}$ & $\begin{array}{c}2 \\
0,8 \%\end{array}$ & 0 & $\begin{array}{c}69 \\
27,5 \%\end{array}$ \\
\hline $\begin{array}{l}\text { Non-Organics (Pesticides, Herbicides, } \\
\text { Insecticies, Chemical Fertilizer) }\end{array}$ & $\begin{array}{c}22 \\
8,8 \%\end{array}$ & $\begin{array}{c}25 \\
10 \%\end{array}$ & 0 & $\begin{array}{c}1 \\
0,4 \%\end{array}$ & $\begin{array}{c}48 \\
19,1 \%\end{array}$ \\
\hline $\begin{array}{c}\text { Semi Organics (Use Both Natural and } \\
\text { Chemicals Fertilizers) }\end{array}$ & $\begin{array}{c}43 \\
17,1 \%\end{array}$ & $\begin{array}{c}91 \\
36,1 \%\end{array}$ & 0 & 0 & $\begin{array}{c}134 \\
53,4 \%\end{array}$ \\
\hline & & & & & 251 \\
\hline
\end{tabular}

the data that has been collected, there are some fundamental differences in cultural patterns related to coffee farming practices with different ethnic backgrounds in the Gayo Highlands, namely: production, maintenance, and the labor management.

Currently, the style of coffee farming in Gayo is synonymous with increasing productivity. This can be seen from the patterns of production, maintenance, and the labor mnagement which are characteristic of largescale agricultural patterns to increase coffee productivity. However, some farmers are still reluctant to use pesticides in the maintenance of coffee plantation, as said by Coffee farmers from Gayo ethnic backgrounds experiencing a dilemma between productivity and a sense of environmentalism, how they think about efforts to maintain quality by implementing quality control certification.

"But if we don't spray our plantation, the result is a little less, right? There is only a dilemma. The government forces us to produce a lot. As a result, we will, of course, use fertilizers. We can get the production from $700 \mathrm{~kg} / \mathrm{ha}$ increases into 1 ton / ha like Vietnam. If that's the target, we will definitely have to use fertilizer. However, until now most of coffee farmers in Gayo have not been too be tempted to increase productivity in such away. This dilemma is actually felt by Gayo farmers when the government forces us to increase, even a few farmers with ordinary knowledge has started using pesticides.

But it depends on from the angle we see. Of course, people want good prices. The government, like this gentleman said, want high production. I thought this way, the trouble is that the merchants get this hit.
But he was also wrong I think, because in the trade contract document there is quality control. For example, can we involve other parties in maintaining the quality of Gayo coffee, such as Department of Health, also the campus, what they can contribute, and the Department of Agriculture and traders, of course in maintaining the quality of Gayo Coffee products. It can only be done by large companies, namely fair trade organizations, namely quality control certification."

As told by the informant regarding the use of fertilizers in maintaining coffee plantation, generally, there were 3 main patterns of coffee care carried out by coffee farmers, both Gayo and Javanese ethnic backgrounds. These patterns are:

Based on the above table, it can be seen that the frequency of coffee farmers using non-organic and semi-organic fertilizers is dominated by transmigrant farmers from Java who have migrated to Gayo. The treatment pattern was distributed by $19.4 \%$ using nonorganic fertilizers and $70.5 \%$ using semi-organic in the treatment pattern for coffee trees. This means that out of 251 respondents working as coffee farmers, almost $50 \%$ or 116 coffee farmers use non-natural fertilizers as a way to maintain and increase coffee productivity.

The difference in treatment patterns using organic and organic fertilizers is certainly a dilemma when it is confronted with the reality of the field. Some of the interviewed respondents admitted that there are different values held by coffee farmers from local communities with migrant communities originating from Java. As told by Pak Irwan about these differences;

"Indeed, the way we treat coffee is different, Gayo farmers treat coffee trees 


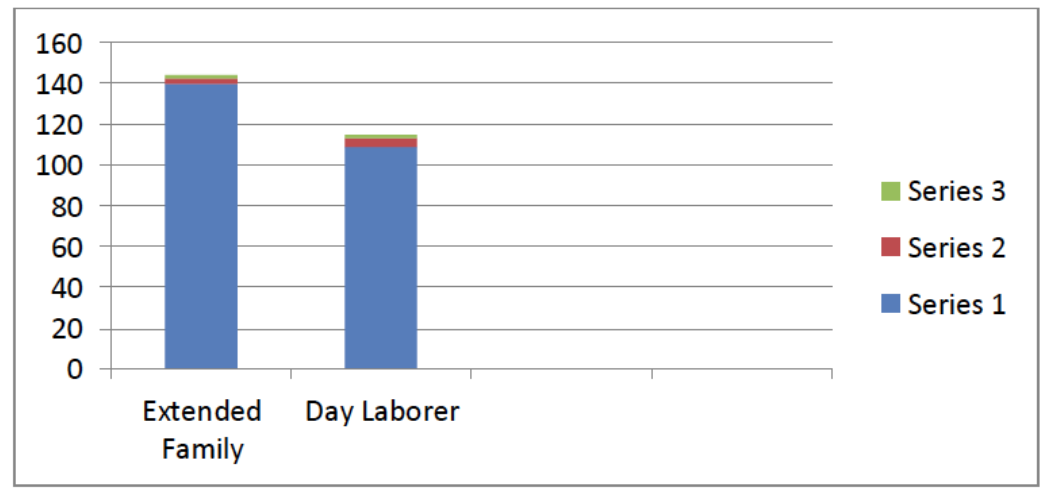

Figure 3: Source of Labors.

the same as they care for their children, but for coffee farmers from outside Gayo, they only make the plantation as a place to make a living. However, we do not accept that our coffee is claimed to use chemicals, because we are coffee addicts, one day one night we can drink up to 15 cups. So, it is impossible for us to use chemicals because we first consumed them ourselves. However, this mistake was made by a small number of farmers, and we are Atu Lintang area, do not use chemicals materials because there is no serious pests in the Atu Lintang plantation area. Coffee disease is in the Bener Meriah area, maybe coffee in the Bener Meriah area uses pesticides".

The different cultural values admitted by the migrants in Gayo and they have their reasons. Coffee plantation is a hope for those oving to a new place with different climatic characteristics from their hometown. Even when they perceive coffee as an intermediary for earning a living, it is a reason and rationality for their perception of the surrounding environment which is very different from their hometown. Moreover, we are faced with the development of the world economy through the introduction of a capital-based economy which can no longer be rejected, so that the economic system adapted is a capital-based economic system in which it is strongly influenced by the use of labor.

In the above picture, it can be seen that the use of labor has become one of the strategies for maintaining and harvesting coffee plantations in the Gayo highlands, done both by Gayo Farmers and Farmers from Javanese migrants. It shows that the number of workers used during the harvest season distributed more than $50 \%$ with the use of more than 3 people.

\section{E. CONCLUSION}

In general, the practice of cultivating coffee among farmers of Gayonese And Javanese ethnic backgrounds has differences in just a few stages of cultivation, namely at the time of planting, fertilizing and maintaining. As it has been explained in the discussion section, there are different variants of farming practices and these differences are evident when the necessity to implement good agricultural practice is applied. The problem of coffee today is not only judged from the quality of the production, but also from the process of treatment, the use of cover crops, and several other environmental aspects.

The different farming variations seen between coffee farmers from two different ethnic backgrounds which can lead to an understanding between them regarding the plant care patterns that should be used, especially with the current development of the world coffee market. However, some native farmers do not agree that farmers who want higher coffee production must use chemical fertilizers instead of organic fertilizers.

From the research data that has been presented, the existence of the local wisdom of the coffee culture applied by Gayo coffee farmers through the symbolization of the 4 elements of life is directly proportional to the statistical results of the survey that has been conducted. Where most Gayo coffee farmers still apply local wisdom in coffee cultivation which focuses on the process of harmony with the surrounding environment. Meanwhile, for coffee farmers with ethnic backgrounds, the cultivation process is not based on the local wisdom values that exist in the local community. Because based on their life experience and mediation structure that has happened for a long time and has happened repeatedly, it causes them to think of coffee gardens as 
a place and source of income for the sake of improving their standard of living.

In general, the efforts made by the two parties who reported the error occurred without reason. Those who have different cultural values base when they assess, see, perceive the experience of the source of livelihood. Externalization of different experiences can give rise to different practices which can be seen from planting and maintenance practices.

\section{REFERENCES}

Achwan, S., Hamid, A. H., \& Romano. (2019). the Impact of Climate Change and Adaptation Strategy of Arabica Coffee Farmers in Central Aceh Regency. Russian Journal of Agricultural and Socio-Economic Sciences, 85(1), 201-206. https://doi.org/10.18551/rjoas.2019-01.24

Bourdieu, P. (1993). The Field of Cultural Production: Essays on Art and Literature, (R. Johnson (ed.)). Polity Press.

Bourdieu, P. (2012). Arena Produksi Kultural; Sebuah Kajian Sosiologi Budaya. Kreasi Wacana .

Jaffe, Roberta and Bacon. 2007. in Confronting the Coffee crisis ; Fair Trade, Suistanable Livelihoods and Ecosystem in Mexico and Central America.Edited by Crhistopher $\mathrm{M}$. Bacon, Et al. MIT Press. Cambridge, London.

Gobbi, J. A. (2000). Is biodiversity-friendly coffee financially viable? An analysis of five different coffee production systems in western El Salvador. Ecological Economics, 33(2), 267-281. https://doi.org/10.1016/S0921-8009(99)00147-0

Haryatmoko. (2016). Membongkar Rezim Kepastian. PT. Kansius.

Hidayat, T. ; Y. R. dan R. (2017). Karakterisktik petani padi peserta program upaya khusus padi, Jagung, Kedelai Pajale di Desa
Ranah Baru Kecamatan Kampar, Kabupaten Kampar. JOM Faperta, 1 Februari(4).

Kamil, A. I. (2019). KOPI: Otentisitas Material Dan Gaya Hidup. Aceh Anthropological Journal, 3(2), 129-143. https://doi.org/10.29103/aaj.v3i2.2777

Levy, D., Reinecke, J., \& Manning, S. (2016). The Political Dynamics of Sustainable Coffee: Contested Value Regimes and the Transformation of Sustainability. Journal of Management Studies, 53(3), 364-401. https://doi.org/10.1111/joms.12144

Mahyuda; Amanah, Siti; Tjitropranoto, P. (2018). Level of Adoption of GAP (Good Agricultural Practice) Gayo Arabica Coffee Cultivation by Farmers in Central Aceh District. Jurnal Penyuluhan, 14(2), 308-323.

Nazaruddin, M., Nirzalin., Nasution Abdullah., Arifin, Awaludin., S. C (2020). A Study of Cultural Dynamics Among Gayo Coffee Farmers in Indonesia. International Journal of Innovation, Creativity and Change. International Journal of Innovation, Creativity and Change., 12(9), 613-626.

Nazaruddin, M. (2019). Orientasi Nilai Dan Habitus Petani (Studi tentang Orientasi Budaya dan Ragam Prilaku Petani Kopi di Dataran Tinggi Gayo).

Prasmatiwi, F. E., Irham, I., Suryantini, A., \& Jamhari, J. (2011). Kesediaan Membayar Petani Kopi Untuk Perbaikan Lingkungan. Jurnal Ekonomi Pembangunan: Kajian Masalah Ekonomi Dan Pembangunan, 12(2), 187. https://doi.org/10.23917/jep.v12i2.192

Puspitawati, P., Hasanah N., Febryani, A., Andriansyah, D. (2020). Kearifan Lokal Petani Kopi Dataran Tinggi Gayo. Yayasan Kita Menulis.

Toledo, V. M., \& Moguel, P. (2012). Coffee and Sustainability: The Multiple Values of Traditional Shaded Coffee. Journal of Sustainable Agriculture, 36(3), 353-377. https://doi.org/10.1080/10440046.2011.583719

Winarni, E. (2013). Pengaruh Jenis Pupuk Organik terhadap Pertumbuhan Tanaman Kopi. Momentum., 9(1), 35-39.

\section{https://doi.org/10.6000/1929-4409.2021.10.112}

(C) 2021 Nazaruddin et al.; Licensee Lifescience Global.

This is an open access article licensed under the terms of the Creative Commons Attribution Non-Commercial License (http://creativecommons.org/licenses/by-nc/3.0/) which permits unrestricted, non-commercial use, distribution and reproduction in any medium, provided the work is properly cited. 